\title{
Kendala Organisasi Berbasis Komunitas dalam Program Pencegahan dan Penanggulangan HIV/AIDS: Studi Kasus pada Dua LSM Peduli AIDS di Jakarta
}

\section{Community Based Organizations' Constraints in HIV/AIDS Prevention Program: Case Study on Two NGOs Cares Aids in Jakarta}

\author{
Ranti Suciati $^{1}$, Mujiati ${ }^{2}$, dan Novianti ${ }^{1}$ \\ 1) Pusat Penelitian dan Pengembangan Upaya Kesehatan Masyarakat, Jalan Percetakan Negara No. 29 Jakarta 10560, \\ Indonesia \\ 2) Pusat Penelitian dan Pengembangan Sumber Daya dan Pelayanan Kesehatan, Jalan Percetakan Negara No. 29 Jakarta \\ 10560, Indonesia \\ Korespondensi: rantisuciati7@gmail.com
}

Submitted: 1 November 2018, Revised: 3 Desember 2018, Accepted: 14 Desember 2018

https://doi.org/10.22435/jpppk.v2i3.761

\begin{abstract}
Abstrak
Semakin meningkatnya jumlah kasus HIVIAIDS di Indonesia, berdampak tidak hanya pada masalah kesehatan, memacu pemerintah untuk melibatkan masyarakat sipil dalam Organisasi Berbasis Komunitas (OBK) untuk ikut berperan dalam upaya pencegahan dan penanggulangan HIVIAIDS. Pentingnya identifikasi kendala atau hambatan yang dihadapi oleh OBK memunculkan strategi atau alternatif solusi untuk mengatasi kendala, serta memberikan gambaran model intervensi yang lebih sinkron antara pemerintah dan masyarakat. Desain penelitian adalah kualitatif dengan melakukan studi kasus di dua LSM Peduli AIDS di Jakarta. Informan dipilih secara purposive sampling yaitu pengurus, anggota/petugas, dan dampingan dari dua OBK. Pengumpulan informasi dengan wawancara mendalam berdasarkan pedoman wawancara dan diolah menggunakan metode content analysis. Kendala yang dihadapi OBK yaitu alur rujukan BPJS yang mengikuti domisili sehingga memberatkan pasien, kurang optimalnya koordinasi dan kerjasama antara OBK dengan Puskesmas, belum meratanya kualitas dan kapasitas SDM anggota OBK, persoalan administratif organisasi, sumber dana yang tidak selalu kontinu, adanya perbedaan kepentingan antara OBK dengan pihak kepolisian, serta masih tingginya stigma masyarakat terhadap penderita HIVIAIDS. Solusi mengatasi kendala OBK dilakukan dengan peningkatan efektifitas pelaksanaan program pemerintah melalui OBK, antara lain dengan penerapan fleksibilitas pengelolaan dana berdasarkan kinerja OBK, peningkatan kapasitas SDM, pemantapan sistem manajerial, pemahaman alur layanan kesehatan di Puskesmas, serta social support bagi penderita HIVIAIDS.
\end{abstract}

Kata kunci: organisasi berbasis komunitas, LSM, HIVIAIDS

\section{Abstract}

The increasing number of HIVIAIDS cases in Indonesia that impact not only on health issues, spur the Government to involve civil society in community-based organizations (OBK) to play a role in HIVIAIDS prevention program. Identification of constraints or obstacles faced by OBK do as they can generate alternative strategies or solutions to overcome these constraints, and provide a more synchronous model of intervention between the government and the community. This type of research is a case study at two AIDS Awareness NGOs in Jakarta. The informants were chosen by purposive sampling ie the board, members/officers, and assistants from the two NGOs. Information collection with by in-depth interview based on interview guideline and processed using content analysis method. Constraints faced by the OBK is the issue of referral flow pathways that follow the domicile so burdensome patients, less optimal coordination and cooperation between OBK 
with primary health care, uneven quality and capacity of human resources of NGO members, organizational administrative issues, sources of funds that are not always continuous, different interests between the OBK with the police department, and the stigma. Reduction of obstacles faced by OBK can be done by increasing the effectiveness of government program implementation through OBK, among others by applying flexibility of fund management based on OBK performance, human resource capacity building, managerial system strengthening, understanding of health service flow in primary health care, and social support for patient HIV/ AIDS.

Keywords: community-based organizations, NGOs, HIVIAIDS

\section{Pendahuluan}

HIV/AIDS menjadi salah satu ancaman kesehatan masyarakat di banyak negara di dunia termasuk Indonesia. Pada tahun 2013 terdapat 35 juta orang di dunia hidup dengan HIV dan 1,5 juta orang meninggal akibat AIDS. ${ }^{1}$ Kasus infeksi HIV/ AIDS telah menjadi masalah kesehatan yang di hadapi oleh banyak negara di dunia. ${ }^{2}$ Menurut data Ditjen PP\&PL sampai dengan tahun 2014 jumlah kasus HIV yang dilaporkan sebanyak 22.869 kasus dan kasus AIDS sebanyak 1.876. Angka kumulatif penderita HIV dari tahun 1987 sampai September 2014 sebanyak 150.296 orang dan jumlah kumulatif AIDS sebanyak 55.799 orang. Prevalensi Kasus AIDS per 100.000 penduduk di Indonesia sampai dengan September 2014 total sebesar 23,48. ${ }^{3}$ DKI Jakarta merupakan salah satu provinsi di Indonesia dengan angka HIV dan AIDS yang tinggi. Menurut data Ditjen PP \& PL jumlah kumulatif kasus HIV di DKI Jakarta sejak tahun 1987 hingga Desember 2014 adalah 32.782 dan angka kumulatif AIDS sebanyak 7.963 kasus. ${ }^{4}$

HIV/AIDS dinilai bukan lagi sebagai masalah kesehatan semata saat ini, tetapi mempunyai implikasi politik, ekonomi, sosial, etis, agama dan hukum bahkan dampak secara nyata, cepat atau lambat menyentuh hampir semua aspek kehidupan manusia. Pemerintah Indonesia melalui Komisi Penanggulangan AIDS (KPA) mulai melakukan strategi respons penanggulangan HIV/AIDS dengan menyusun rencana Strategi Nasional Penanggulangan AIDS (STRANAS) setiap lima tahun. Salah satu prinsip dalam upaya penanggulangan HIV/AIDS adalah penyelenggaraannya dilakukan oleh masyarakat dan pemerintah secara bersama berdasarkan prinsip kemitraan. $^{5}$

Upaya penanggulangan yang terbatas dan tak terkoordinasi tidak akan mampu mengendalikan epidemi HIV/AIDS di Indonesia sehingga perlu dilakukan perubahan dalam status, keanggotaan maupun tata kerja dariKomisi Penanggulangan AIDS Nasional (KPAN). Perpres nomor 75 tahun 2006 menandai terjadinya intensifikasi penanggulangan AIDS di mana keanggotaan KPA Nasional diperluas dengan mengikutsertakan masyarakat sipil. Keterlibatan masyarakat sipil dalam Organisasi Berbasis Komunitas (OBK) memegang peran penting dalam upaya penanggulangan HIV/AIDS ${ }^{6}$ dan telah menjadikannya sebagai salah satu pemain utama dalam penanggulangan HIV/AIDS di Indonesia. $^{7}$

Salah satu bentuk pelibatan masyarakat sipil adalah dengan mengajak warga masyarakat biasa untuk terlibat dalam upaya pencegahan dan penanggulangan HIV/AIDS. Sejumlah studi di beberapa negara telah membuktikan bahwa melibatkan partisipasi masyarakat dalam program pencegahan dan penanggulangan masalah $\mathrm{HIV} /$ AIDS membuahkan hasil yang positif. ${ }^{8}$ Salah satu bentuk atau komponen partisipasi masyarakat dalam program HIV/AIDS adalah konsep Community Based Organizations atau CBOs. ${ }^{6}$

"Community based organisations (CBOs) represent a more organised effort to combat HIV. These organisations are created by community members, have their headquarters in the community and collaborate with the local health authorities to achieve prevention, treatment, care and support goals. Their range of activities depends on their individual mission statements, but they may be involved in home-based care, voluntary counselling and testing, patient identification and referral, subsidy of health-related costs, research, data collection and local health area decisionmaking”.

CBOs digambarkan sebagai suatu upaya yang lebih teroganisir untuk melawan HIV. 
Organisasi ini dibentuk oleh anggota masyarakat, memiliki tempat sebagai pusat kegiatan di masyarakat dan bekerja sama dengan pemerintah setempat untuk mencapai tujuannya. Aktivitas CBOs tergantung pada tujuan individu-individu ada di dalamnya, mereka dapat melibatkan diri dalam upaya membantu perawatan, VCT, identifikasi pasien, membantu usaha pembiayaan, penelitian, pengumpulan data dan pengambilan keputusan dalam sektor kesehatan dalam area lokal.

Organisasi berbasis komunitas mempunyai kemampuan lebih yang membuatnya berada dalam posisi strategis untuk merespon masalah HIV/ AIDS. Beberapa kelebihan dari OBK pertama adalah mereka lebih memahami kebutuhan komunitas yang mereka layani, karena mereka sendiri adalah bagian dari komunitas tersebut, mereka dapat menjembatani kebutuhan masyarakat dengan penyedia layanan dari pemerintah. ${ }^{9}$ Kedua, OBK memiliki kemampuan yang lebih dalam menjangkau kelompok-kelompok masyarakat yang terisolir secara sosial maupun geografis karena stigma dan marjinalisasi. Ketiga, bentuk organisasi berbasis komunitas yang bersifat fleksibel, tidak terikat birokrasi yang dapat memudahkan mereka menyesuaikan pendekatan kepada masyarakat lokal, termasuk pendekatanpendekatan inovatif. Keempat, OBK dapat bekerja secara efisien karena banyak kegiatannya didukung oleh sumber daya yang sifatnya sukarela. ${ }^{9}$

Penelitian di India yang dilakukan oleh AIDStar-One, menggali bagaimana peran dan strategi organisasi berbasis komunitas yaitu Sarathi dan Prerana Sarajik Sansta dalam melakukan program penanggulangan HIV/AIDS di kalangan lelaki seks dengan laki-laki (LSL) dan Wanita Penjaja Seks (WPS). Sarathi adalah sebuah organisasi komunitas peduli HIV/AIDS yang terdiri dari LSL, para anggota komunitas tersebut melakukan kegiatan penjangkauan, mendatangi tempat-tempat khusus yang biasa dikunjungi komunitas LSL, mengumpulkan data profil LSL, membangun jaringan komunikasi informal antara mereka, melakukan pendampingan untuk VCT dan membantu memfasilititasi akses pada layanan kesehatan. ${ }^{10}$ Sedangkan organisasi Prerana Sarajik Sansta anggotanya terdiri dari WPS, mereka mensosialisasikan pentingnya berperilaku seks yang aman (penggunaan kondom) kepada para WPS.
Selain itu, mereka juga membantu memfasilitasi akses terhadap layanan kesehatan. ${ }^{10}$

Organisasi berbasis komunitas seperti Sarathi dan Prerana Sarajik Sansta dinilai lebih efektif dan bisa lebih diterima oleh individu-individu yang menjadi target atau sasaran program, selain itu kemungkinan program penanggulangan HIV/AIDS dapat lebih terjaga keberlanjutannya. ${ }^{10}$ India adalah salah satu negara yang membuat kebijakan program HIV/AIDS dengan melibatkan Non Government Organization (NGO) atau Community Based Organizations (CBOs) sebagai ujung tombak dalam manajemen program penanggulangan HIV/AIDS bagi populasi berisiko (Most At Risk Populations/ MARPs). Hasilnya adalah adanya peningkatan cakupan intervensi program HIV/AIDS dari 5\% pada tahun 2005 menjadi $13 \%$ pada tahun 20062007..$^{10}$

Contoh upaya sukses lain dalam penanggulangan HIV/AIDS adalah dari negara Malaysia yang memiliki The Code of Practice (COP) tentang Pencegahan dan Manajemen HIV/AIDS di tempat kerja. COP ini disiapkan oleh Departemen Keselamatan dan Kesehatan Kerja, Kementerian Sumber Daya Manusia Malaysia dan bekerjasama dengan perwakilan dari berbagai lembaga pemerintah, organisasi non-pemerintah (LSM) dan organisasi internasional. COP ini bertujuan untuk memberikan pedoman bagi pencegahan dan penanggulangan HIV/AIDS di tempat kerja, memberikan informasi dan kesadaran tentang HIV/ AIDS, dan mempromosikan lingkungan kerja yang tidak diskriminatif. Contoh kegiatan yang dilakukan dalam rangka peningkatan kesadaran tentang pentingnya HIV/AIDS di tempat kerja yaitu tes HIV secara sukarela, pameran, talk series, pertunjukan, dan berbagi pengalaman dari orang yang hidup dengan HIV/AIDS (ODHA). Program peningkatan kesadaran ini berkoordibasi dengan lembaga swadaya masyarakat dan Unit Promosi Departemen Kesehatan. ${ }^{11}$

Menurut data Kementerian Kesehatan RI, sampai dengan Juni 2014, prevalensi kasus AIDS per 100.000 penduduk di Indonesia sebesar $23,41 \%$. Provinsi yang menduduki 4 terbesar dengan jumlah kumulatif penderita HIV/AIDS adalah DKI Jakarta, Jawa Timur, Papua dan Jawa Barat. LSM Peduli AIDS di Jakarta ada banyak dan dalam pelaksanaan 
kegiatannya tidak menutup kemungkinan adanya tantangan dan kendala yang dapat berpengaruh pada keberhasilan program pencegahan dan penanggulangan HIV/AIDS. Karenanya, tulisan yang merupakan bagian dari hasil Riset Pembinaan Kesehatan (Risbinkes) tahun 2015 ini mencoba membahas kendala apa saja yang dihadapi oleh dua LSM Peduli AIDS di Jakarta dalam kegiatan pencegahan dan penanggulangan HIV/AIDS.

\section{Metode}

Penelitian kualitatif ini dilakukan dengan studi kasus di dua LSM Peduli AIDS di Jakarta pada tahun 2015. Pengumpulan data kualitatif dilakukan melalui wawancara mendalam menggunakan pedoman wawancara. Informan yaitu pengurus, anggota/petugas, dan dampingan dari dua LSM Peduli AIDS di Jakarta yang dipilih secara purposive sampling. Hasil survei pendahuluan diperoleh informasi dari Forum LSM Peduli AIDS bahwa di Jakarta ada sekitar 35 organisasi LSM Peduli AIDS. Pemilihan dua LSM Peduli AIDS yaitu LSM "A" dan LSM "B" didasarkan pada pertimbanganpertimbangan yaitu: 1) keduanya sama-sama memiliki program penjangkauan pengguna napza suntik (penasun), 2) wilayah kerja hampir sama, dan 3) LSM "A" adalah LSM yang sudah berdiri cukup lama dan sudah lebih mapan, sedangkan LSM "B" adalah LSM yang baru mulai diaktifkan kembali setelah sebelumnya vakum. Data yang telah dikumpulkan kemudian diolah menggunakan metode content analysis, yaitu metode yang digunakan untuk mengetahui kecenderungan isi komunikasi. Untuk data kualitatif, pengolahan dilakukan melalui tahapan penyusunan transkrip wawancara yang selanjutnya ditranformasi menjadi matriks untuk memetakan kaitan antara variabel satu dengan lainnya. Matriks berisi kelompok tema-tema berdasarkan hasil yang diperoleh dari wawancara dengan informan. Dari penelitian ini, kendala yang ditemukan dari hasil wawancara dapat dikelompokkan ke dalam tema-tema berikut, yaitu: kendala alur rujukan BPJS, kendala koordinasi dan kerjasama, kendala kualitas dan kapasitas SDM anggota OBK, kendala administratif organisasi, serta kendala sosial lainnya (adanya perbedaan kepentingan dan stigma).

\section{Hasil}

LSM "A" didirikan pada tahun 2001 dan telah terdaftar di Kementerian Hukum dan HAM serta telah memiliki Surat Keputusan (SK) dari Kementerian Hukum HAM dan Dinas Sosial. Jumlah anggota LSM "A" sebanyak 32 orang. Kegiatan awal LSM "A" adalah penanggulangan narkotika melalui pusat pemulihan atau panti rehabilitasi untuk pengguna napza, kemudian berkembang sesuai dengan program dan target yang ditetapkan oleh lembaga donor. Kegiatan di LSM "A" yaitu 1) Program penjangkauan pengguna napza suntik (penasun) melalui pembagian jarum suntik steril kepada kelompok pengguna napza suntik (harm reduction - pengurangan dampak buruk), menyisipkan informasi tentang HIV, mengajak mereka untuk mengikuti program rehabilitasi (Pemulihan Adiksi Berbasis Masyarakat/PABM), dan clean day, yaitu membersihkan jarum suntik yang dibuang sembarangan dan berserakan di sekitar spot; 2) VCT (Voluntary Counseling and Testing); 3) Peer support, dan 4) Support group.

Beberapa lembaga donor di LSM “A” yaitu Family Health International-Aksi Stop AIDS (FHIASA), HIV Coorporation Program for Indonesia (HCPI), Komisi Penanggulangan AIDS Nasional (KPAN), AUSAID melalui Research Triangle Institute (RTI) atau yang biasa disebut dengan SUM, Alliance melalui organisasi Rumah Cemara, Badan Narkotika Nasional (BNN) dan Kementerian Sosial. Dalam pelaksanaan kegiatan, beberapa kendala yang dihadapi oleh LSM "A" yaitu peraturan mengenai alur BPJS yang mengikuti domisili pasien membuat pasien merasa segan untuk mengakses layanan kesehatan sehingga ada pasien yang memilih untuk putus obat.

“...sistem BPJS kan ikut domisili, kalau dia tinggal di daerah X maka harus ke Puskesmas X. Dan itu merujuk harus ke RSUD. Kalau seandainya dia mau ambil obat ke RS Z, dia harus ke RSUD Y dulu baru kemudian ke Z. Jadi banyak yang punya BPJS pun tapi mereka punya uang, gak mereka pakai itu BPJS, mending pakai uang sendiri dulu daripada ribet kan proses dan alurnya itu. Adapun yang memang alurnya begitu akhirnya dia putus obat." (AM, Penjangkau)

Kendala lain yang dihadapi oleh LSM "A" yaitu petugas puskesmas yang tidak selalu ada 
ditempat atau melakukan pekerjaan multifungsi, juga dapat menghambat para petugas penjangkau di lapangan untuk mengakses layanan kesehatan.

"Biasanya dari petugas layanan, kalau dampingan mau akses jarum suka gak ada di tempat. Kadang-kadang nanti (petugas puskesmas) dipekerjakan di mana, apalagi kader yang sebagian udah UMR, yang harus dipekerjakan di bagian apa lah. Kader muda itu dibuat multi, itu kadang dampingan mau akses jarum gak dapet. Karena LASS-nya (Layanan Alat Suntik Steril) ini kan beda, LASS kan kadang-kadang kadernya inian karcis, kadernya dipekerjakan di situ." (YN, Penjangkau)

Para petugas penjangkau juga terkendala oleh kebijakan alur layanan puskesmas yang berbeda-beda, yang terkadang menyulitkan, misalnya di salah satu puskesmas, dampingan LSM yang berniat mengakses ARV harus bolak-balik melakukan VCT ulang, pemeriksaan darah ulang, foto torax, pemeriksaan CD4, padahal sudah terbukti positif HIV.

"Alur layanan puskesmas yang beda-beda kebijakannya, kalau di Puskesmas 'P' kaya gitu, padahal kita udah program SUFA yang gak perlu pemeriksaan CD4, Torax tapi di sana ada." (BNK, Penjangkau)

Kualitas SDM dirasa masih belum semuanya bagus sehingga diperlukan pengembangan kapasitas.

"Kapasitas SDM ini memang ada yang baguuuss..., ada yang biasa-biasa aja, ada yang perlu terus kita dorong. Terutama tim teknis ini yach mba, hampir $90 \%$ itu pengguna napza." (WK, Divisi Pengembangan Organisasi)

Sumber dana LSM sebagian besar berasal dari bantuan lembaga donor yang sifatnya tidak kontinu, sehingga selalu menjadi kendala dalam bekerjanya lembaga. Untuk memperpanjang kerja sama LSM harus mengajukan proposal terlebih dahulu dan setelah beberapa bulan jika disetujui, baru bisa direalisasikan. Persyaratan administrasi untuk pertanggungjawaban ke lembaga donor dirasa cukup rumit dan sangat menyita waktu, sehingga berakibat pada tertundanya kegiatan lain, seperti misalnya kegiatan kapasitasi SDM.

"Karena kita orang terbatas, chief-chiefnya terbatas, kita gak bsia ngasih mereka peningkatan kapasitas, kadang kita nunggu atau minta ke donor buat datengin ngelatih. Kenapa kita gak bisa? Karena kita sibuk banget gak sih? Itu dia tadi administratif bikin sibuk banget." (AF, Divisi Penjangkauan)

Kendala lain yang dihadapi oleh LSM "A" terutama oleh kelompok dampingan dalam upaya pencegahan dan penanggulangan HIV/AIDS yaitu masih adanya stigma dari masyarakat.

“....banyak juga ketemu keluarga yang kurang mendukung, masyarakatnya, masalah stigma lah. Kalau keluarga, ah udah lah biarin aja, gak usah diurusin, mau gimana kek,mau mati kek, kaya gitu. Masyarakat istilahnya ngejengkelin, ah dia make, berhenti, ntar juga make lagi. Saya ngeliat diri saya sendiri juga dulu begitu. Pelanpelan sih emang." (BNK, Penjangkau LSM “A”).

Sedangkan di LSM "B" yang berdiri pada tahun 2001 dengan jumlah anggota hingga penelitian berlangsung sebanyak 15 orang. Kegiatan awal LSM "B" adalah penyuluhan kesehatan reproduksi ke masyarakat, kemudian tahun 2004-2009 dilibatkan dalam program penjangkauan para pengguna napza suntik oleh FHI (Family Health International) dan berlanjut pada kegiatan penjangkauan penasun. Sejak tahun 2012, LSM "B" vakum karena putus project dengan lembaga donor. Tahun 2014, LSM "B" mulai aktif kembali dan menjalankan dua proyek dari Global Fund yaitu penjangkauan dan pendampingan penasun dan penjangkauan Lelaki Berisiko Tinggi (LBT). LSM "B" melalui Program SUFA juga melakukan pendekatan persuasif agar ODHA yang putus obat mau melanjutkan program terapi ARV-nya dan bagi yang belum mengakses obat dibujuk untuk mau memulai terapi ARV.

Dalam pelaksanaan kegiatan, beberapa kendala yang dihadapi oleh LSM "B" yaitu belum adanya SK/ akta pendirian LSM "B" sebagai salah satu syarat administratif dalam mengajukan funding kepada lembaga donor. Kendala lain yaitu adanya beda kepentingan antara pihak kepolisian dan LSM khususnya dalam kegiatan pendistribusian jarum suntik steril.

“...... biasanya saat bagikan jarum suntik steril ada aparat kepolisian yang memegang atau menangkap kita. Sebagai petugas lapangan karena ada surat tugas ya aman lah itu. Kalau berurusan dengan aparat yang kasian malah dampingan kita, waktu itu mau diangkut dan ditangkap dia, karena kan status dia sebagai pengguna, padahal BB 
(Barang Bukti) tidak ada kan... yah paling jarum suntik steril doank. Tapi polisi kan juga punya kepentingan mau dapat informasi dari dampingan kita dia beli atau dapat barang narkoba itu di mana kan... Ada gesekan kepentingan sih klo kita petugas lapangan dengan aparat kepolisian." (IYN, Penjangkau)

Sama dengan LSM "A", LSM "B" juga terkendala dengan keberlangsungan lembaga donor dalam memberikan dana kegiatan. Adanya dua sumber dana dari dua lembaga donor yang berbeda menjadikan besaran gaji yang diterima oleh masing-masing anggota juga berbeda dan seringkali menimbulkan rasa iri diantara petugas/anggota LSM. Besaran gaji yang diterimapun dirasakan masih sangat kurang. Selain itu, terbatasnya dana operasional menyebabkan terhambatnya kegiatan pendekatan petugas lapangan kepada dampingan di lapangan.

"Gak bisa menutup mata juga karena mereka banyak yang udah kenal uang, kenal funding, kenal donor. Memang kita disini terbuka dan transparan mengenai keuangan dan donor, tapi yang jadi kendala kadang beda donor beda insentif kan untuk petugas lapangan. Ada beberapa kasus, timbul rasa iri sesama petugas lapangan.., ribut dan akhirnya kadang ada yang mengundurkan diri meskipun kadang masih bisa kita atasin." (BNZ, Direktur Program)

Kendala terkait SDM yang dihadapi LSM "B" yaitu keterbatasan dalam jumlah sehingga seorang petugas/anggota dituntut untuk multi peran. Kualitas SDM juga dirasa masih terbatas sehingga nilai tawar dengan lembaga donor pun lemah.

"Kadang-kadang kita kurang nilai tawar. Nilai tawar kita itu kurang, kenapa? Kalau SDMnya kita bagus, fund rising kita punya, kita kan belum ada fund rising...jadi tidak punya nilai tawar. Jadi mempertimbangkan kita semua itu udah... nah ini kan balik-balik lagi kan ke SDM." (JNT, Program Manager)

Stigma juga masih menjadi kendala yang harus dihadapi oleh petugas lapangan LSM "B".

Masih ada ketakutan stigma kata HIV, itu masih tetep ada. Oke dengan ODHA-nya tidak, tapi dengan kata HIV-nya untuk pemeriksaan HIV itu mereka bilang ngapain periksa HIV, gue gak kok.
Jadi masih ada stigma terhadap kata-kata HIV atau VCT. (HND, Petugas Penjangkau)

\section{Pembahasan}

Masyarakat (community) yang menjadi relawan, aktivis atau petugas penjangkau orang dengan HIV/AIDS (ODHA) menjadi penggerak perubahan sosial di masyarakat melalui kegiatan edukasi, pencegahan, dan perawatan pada orangorang yang berisiko tinggi terkena virus ini. Sejumlah studi di beberapa negara telah membuktikan bahwa dengan melibatkan partisipasi masyarakat dalam program pencegahan dan penanggulangan masalah HIV/AIDS membuahkan hasil yang positif. ${ }^{9}$

Aspek legal formal dari sebuah organisasi seperti lembaga swadaya masyarakat merupakan hal yang sangat penting karena bukan hanya menyangkut ketentuan hukum atau pengakuan pemerintah terhadap lembaga tersebut, namun secara lebih luas legalitas berpengaruh terhadap keleluasaan gerak organisasi itu sendiri. LSM "B" yang belum memiliki akta atau SK mengalami kesulitan dalam menjalin kerja sama program dengan lembaga donor secara langsung, sehingga sulit mendapatkan dukungan dana untuk menjalankan program-program terkait pencegahan dan penanggulangan HIV/AIDS.

Ketidakpastian adanya sumber dana dan keterbatasan dana operasional menjadi kendala yang dihadapi oleh LSM dalam mengimplementasikan rencana kegiatan dan program-programnya. Dana penanggulangan HIV/AIDS dari APBN dan APBD untuk LSM masih terbatas dan tidak kontinu yang berakibat pada rentannya keberlanjutan LSM. Hasil studi banding yang dilakukan oleh pemerintah pusat, pemerintah daerah dan LSM dari Indonesia ke Australia dan Malaysia terkait pembiayaan bagi LSM dalam program penanggulangan HIV/ AIDS merekomendasikan adanya fleksibilitas pengelolaan pendanaan yang tetap berorientasi pada kinerja optimal, akuntabilitas, profesionalisme dan transparansi agar efektifitas pelaksanaan program pemerintah melalui LSM Peduli AIDS dapat ditingkatkan. ${ }^{12}$

Selain terkendala dana, LSM Peduli AIDS juga masih memiliki hambatan dalam membantu dampingan mendapatkan layanan kesehatan. Alur layanan di fasilitas pelayanan kesehatan 
yang berbeda-beda serta kesiapsiagaan petugas kesehatan dalam memberikan layanan masih dirasa menjadi kendala bagi dampingan dan petugas LSM. Perbedaan alur layanan tersebut terutama untuk pasien dengan program SUFA (Strategic Use of ARV). SUFA diluncurkan pada pertengahan tahun 2013 oleh Kementerian Kesehatan dengan tujuan meningkatkan cakupan tes HIV, cakupan ART serta retensi terhadap ART. Dalam pelaksanaannya, SUFA menitikberatkan pada TOP atau Temukan, Obati, dan Pertahankan. Temukan yang Positif yaitu menawarkan tes HIV kepada semua orang yang memiliki perilaku berisiko, kepada ibu hamil, pasien TB, Hepatitis, IMS, pasangan ODHA, dan populasi kunci. Obati yang ditemukan yaitu memberikan pengobatan bagi mereka yang sudah memulai pengobatan Antiretroviral (ARV) secara dini bila jumlah CD4 350 atau tanpa melihat jumlah CD4-nya pada ODHA dengan stadium klinis AIDS 3 atau 4, ibu hamil, pasien TB, pasien Hepatitis dan populasi kunci yang HIV positif. Pertahankan yang diobati yaitu memastikan pasien untuk patuh minum obat seumur hidup dengan memberikan pendampingan terutama pada awal pengobatan, serta memberikan dukungan yang tepat dari keluarga, komunitas, kelompok dukungan sebaya dan layanan kesehatan. ${ }^{12}$ Perbedaan alur layanan di tiap fasilitas pelayanan kesehatan tingkat pertama yaitu Puskesmas mengindikasikan adanya perbedaan pemahaman dan pengertian dari sisi penyedia layanan. Namun tidak menutup kemungkinan pula terdapat perbedaan persepsi dalam mengartikan program SUFA dari sisi pengguna layanan. ${ }^{13}$

Kendala lain yaitu terkait proses dan alur rujukan pasien dengan BPJS yang dirasakan masih rumit, sehingga ada pasien yang kemudian putus obat. Padahal, kepatuhan dalam minum ARV merupakan salah satu faktor yang dapat memperpanjang usia harapan hidup orang dengan HIV/AIDS. Kerumitan proses dan alur juga dirasakan masyarakat pada program Jamkesmas yang ditunjukkan dari hasil studi di Kecamatan Baturetno, Kabupaten Wonogiri. Angka kunjungan masyarakat miskin yang menggunakan kartu Jamkesmas ke Puskesmas meningkat, namun masyarakat masih mengeluhkan tentang syarat rujukan yang dinilai terlalu banyak, alurnya berbelitbelit dan menyulitkan sehingga pasien harus menunggu lama untuk mendapatkan pelayanan. ${ }^{14}$

Di sisi lain, kesulitan rujukan yang dirasakan oleh petugas LSM dan dampingan dalam memperoleh layanan kesehatan bisa jadi disebabkan oleh ketidaktahuan dan ketidakpatuhan terhadap sistem rujukan yang telah ditetapkan. Hasil studi kualitatif tentang pelaksanaan JKN oleh BPJS di Kecamatan Tinanggea, Kabupaten Konawe Selatan menunjukkan bahwa sistem rujukan yang dijalankan oleh Puskesmas Tinanggea adalah sistem rujukan berjenjang yang telah mengacu pada sistem rujukan dari BPJS Kesehatan. Namun masih banyak masyarakat yang belum tahu dan kepatuhan masyarakat terhadap system rujukan tersebut masih rendah. ${ }^{15}$

Petugas kesehatan yang tidak standby di tempat layanan juga menjadi salah satu kendala bagi petugas LSM dan dampingan untuk mengakses layanan kesehatan. Sumber Daya Manusia (SDM) Kesehatan merupakan komponen kunci dalam menggerakkan pembangunan kesehatan. Menurut teori L.Green, perilaku pemanfaatan layanan kesehatan ditentukan atau terbentuk dari tiga faktor, yaitu faktor predisposisi (predisposing factors), faktor pendukung (enabling factors), dan faktor pendorong/penguat (reinforcing factors). Ketersediaan fasilitas, sikap, dan perilaku para petugas kesehatan termasuk dalam faktor pendorong/penguat dalam tindakan memanfaatkan pelayanan kesehatan. ${ }^{16}$

Permasalahan SDM Kesehatan yang masih dihadapi antara lain jumlahnya belum memadai dan mutu SDM Kesehatan yang masih harus ditingkatkan. Hasil studi di Rio de Janeiro, Brazil menunjukkan bahwa mayoritas dokter yang diwawancarai merasa bahwa dialog pasien dan penyedia layanan membantu meningkatkan dan mempertahankan kepatuhan pasien dalam terapi ARV. Namun, keterbatasan waktu yang dimiliki oleh dokter menyebabkan dokter mengalihkan pasien ke petugas kesehatan lain (konselor atau perawat) yang dirasa memiliki waktu lebih banyak untuk berdialog dengan pasien. ${ }^{17}$

Kapasitas petugas LSM dinilai masih belum kompetitif, sehingga diperlukan peningkatan kapasitas melalui pelatihan-pelatihan. Peningkatan kapasitas SDM melalui pelatihan dapat meningkatkan posisi tawar (bargaining position) 
LSM dihadapan para lembaga donor/pembiayaan LSM karena lembaga donor berorientasi pada keberhasilan program, dan keberhasilan program akan sangat bergantung pada kemampuan dan profesionalitas LSM termasuk didalamnya tim dan pekerja LSM dalam menjalankan kegiatan-kegiatan untuk tercapainya target yang diharapkan oleh lembaga-lembaga donor. Peningkatan kapasitas SDM pada LSM Peduli AIDS memerlukan manajemen SDM yang efektif di mana terjadi kesinambungan diantara tiga elemen penting kerja sama yaitu komunikasi yang efektif, respek dan kepercayaan. ${ }^{18}$

Kerja sama petugas LSM pada tingkatan horizontal (sesama petugas penjangkauan) maupun vertikal dengan manajer atau pengawas di atas ketiga elemen tersebut sangatlah penting untuk menghindari kemungkinan terjadinya konflik diantara sesama petugas lapangan (penjangkauan) dan antara petugas lapangan dengan pengawas atau manajer mereka. Aspek komunikasi yang efektif meliputi arus informasi mengenai hambatan yang ditemukan oleh petugas dalam melakukan penjangkauan atau sosialisasi harus dapat dikomunikasikan untuk mendapatkan solusi secara bersama-sama dan pandangan petugas lapangan harus diperhitungkan oleh pengambil keputusan di level yang lebih tinggi seperti pengawas ataupun manajer. Selain itu, komunikasi yang efektif melibatkan penyampaian informasi yang akurat diantara anggota-anggota organisasi dan upaya untuk mendapatkan solusi dan pengambilan keputusan yang paling efektif. ${ }^{18}$

Aspek kedua yaitu respek yang merupakan salah satu aspek yang seringkali terabaikan dalam sebuah organisasi LSM hal tersebut disebabkan karena anggota LSM yang menempati jabatanjabatan struktural yang lebih tinggi tidak memberikan apresiasi kepada anggota yang secara struktural memiliki jabatan di bawahnya ${ }^{18}$ (manajer yang tidak respek kepada petugas lapangan dan mungkin juga sebaliknya). Kepercayaan merupakan salah satu modal sosial yang juga menentukan berkembang tidaknya sebuah organisasi. ${ }^{19}$ Kepercayaan turut mendorong dan memfasilitasi terjadinya koordinasi diantara anggota-anggota organisasi termasuk LSM. Apalagi organisasi dengan tipologi budaya seperti halnya LSM merupakan lembaga yang menggunakan dasar kesukarelaan dalam menjalankan program-programnya untuk peningkatan kualitas hidup masyarakat yang rentan secara sosial dan ekonomi. ${ }^{20}$ Dengan dilakukannya 3 aspek tersebut, meskipun tim di LSM melakukan lebih dari satu peran dan tugas akan meminimalisir terjadinya konflik diantara tim kerja dalam LSM.

Peningkatan kapasitas SDM perlu diusahakan untuk meminimalisir terjadinya konflik internal organisasi akibat ketiadaan komunikasi, rasa respek dan kepercayaan diantara anggota $\mathrm{LSM},{ }^{20}$ peningkatan kapasitas SDM juga perlu dilakukan dengan melakukan training-training yang secara khusus ditujukan untuk meningkatkan kemampuan petugas lapangan dalam hal penjangkauan dan sosialisasi pencegahan HIV/AIDS di tingkat masyarakat, peningkatan kemampuan petugas donor funding dalam membuat proposal donor (anggota LSM yang diberikan tanggung jawab untuk memenangkan proposal lembaga donor), serta kemampuan anggota pada level manajerial untuk menjaga kerja sama dengan institusi-institusi eksternal antara lain fasilitas layanan kesehatan, kementerian/lembaga terkait yang berhubungan dengan produk hukum dan kebijakan.

Salah satu hambatan paling besar dalam pencegahan dan penanggulangan HIV/AIDS di Indonesia adalah masih tingginya stigma dan perlakukan diskriminasi terhadap orang dengan HIV/AIDS. Stigma berasal dari pemikiran seseorang atau dalam skala lebih luas adalah pemikiran masyarakat yang mempercayai bahwa orang dengan HIV/AIDS adalah individu dengan perilaku amoral yang tidak dapat diterima oleh masyarakat secara sosial. ${ }^{20}$ Stigma terhadap ODHA terlihat dengan sikap sinis, perasaan ketakutan yang berlebihan dan pengalaman negatif terhadap ODHA. Bahkan tidak sedikit yang beranggapan bahwa ODHA layak untuk mendapatkan hukuman akibat perbuatannya sendiri dan hukuman itu adalah eksklusi secara sosial (pengucilan secara sosial).

Stigma masih menjadi kendala bagi petugas LSM dalam membantu dampingan memperoleh status kesehatan yang diinginkan. Sebuah penelitian yang di lakukan di Afrika pada tahun 2007 menunjukkan bahwa stigma terhadap penderita HIV/AIDS berdampak pada terganggunya proses pencegahan, penetapan diagnosa dan pengobatan 
para penderita. Hal tersebut dikarenakan stigma negatif yang melekat pada penderita HIV/AIDS telah terinternalisasi pada masyarakat sekitar penderita khususnya keluarga inti dari penderita. Para penderita HIV/AIDS di dunia, seperti di Indonesia $^{21}$, di Cape Town Afrika ${ }^{22}$ dan di China ${ }^{23}$ mengalami diskriminasi secara sosial ekonomi akibat infeksi HIV yang dideritanya.

Terkait dengan diskriminasi, Kamboja sebagai salah satu negara ASEAN sedang berupaya mencapai prinsip "Three Zeros" di tahun 2020, yaitu zero new HIV infection, zero stigma and discriminatin, and zero AIDS-reklated death. Salah satu kebijakan yang diterapkan di tempat kerja adalah pencegahan HIV/AIDS, mitigasi dampak HIV/AIDS pada anggota serikat pekerja dan keluarganya, perawatan dan dukungan terhadap ODHA, penghapusan stigma dan diskriminasi terhadap ODHA. Pemerintah memberikan penghargaan khusus bagi perusahaan atau tempat kerja yang telah melakukan upaya-upaya untuk pencegahan dan penanggulangan HIV/AIDS, dan sebanyak 511 dari 553 perusahaan telah menerima penghargaan tersebut mulai dari tahun 2009 hingga 2013. ${ }^{11}$

Tingginya penolakan masyarakat dan lingkungan akan kehadiran orang yang terinfeksi HIV/AIDS menyebabkan sebagian ODHA hidup dengan menyembunyikan statusnya. Tingginya stigma negatif terhadap HIV/AIDS juga berdampak besar pada program pencegahan dan penanggulangan HIV/AIDS termasuk kualitas hidup ODHA. Dalam hal penjangkauan misalnya sebagai salah satu program pencegahan, stigma terhadap ODHA yang sangat negatif membuat banyak pengguna jarum suntik dan pekerja seks yang berpotensi terinfeksi HIV/AIDS menghindar dan menolak untuk dilakukan test VCT karena takut mendapatkan sanksi sosial jika didiagnosa ODHA, padahal semakin cepat diketahui jika seseorang terinfeksi HIV/AIDS maka kualitas hidupnya dapat ditingkatkan dengan pengobatan yang tepat. ${ }^{24,25,26}$

Stigma muncul karena tidak tahunya masyarakat tentang informasi HIV yang benar dan lengkap, khususnya dalam mekanisme penularan HIV, kelompok orang yang berisiko tertular HIV dan cara pencegahannya termasuk penggunaan kondom dan jarum suntik steril. Sebuah penelitian yang dilakukan di Korea menunjukkan bahwa stigma dan konstruksi kebencian secara sosial yang ada di masyarakat terhadap ODHA membuat penderita HIV enggan melakukan tes untuk mengetahui status kesakitannya karena apabila hasilnya menunjukkan positif, mereka takut akan ditolak oleh lingkungan keluarga, lingkungan sekitar tempat tinggal khususnya oleh pasangan mereka. Tidak masyarakat juga akan menghalangi ODHA untuk melakukan aktivitas sosial. Sehingga banyak dari mereka yang terbukti positif ODHA kemudian menutup diri dan cenderung tidak bersedia melakukan interaksi secara sosial.

Pengalaman kedua LSM yang menjadi subjek penelitian ini pun menunjukkan pengalaman yang sama yaitu mengalami hambatan untuk melakukan pencegahan dan penanggulangan HIV/ AIDS karena masih tingginya stigma mengenai penderita HIV/AIDS sehingga untuk penjangkauan para petugas lapangan mengalami kesulitan karena sering kali pengguna jarum suntik atau wanita penjaja seks yang menjadi "target" penjangkauan kedua LSM tersebut menolak untuk diperiksa VCT untuk penegakkan diagnosa HIV atau tidak. Selain itu tidak jarang juga mereka yang telah melakukan tes VCT dan dinyatakan positif ODHA ketika akan dibawa untuk mendapatkan layanan kesehatan menolak bahkan ada yang sampai tibatiba menghilang dan tidak bisa dikontak. ${ }^{27}$ Kondisi tersebutlah yang menjadi kendala organisasi berbasis komunitas dalam program pencegahan dan penanggulangan HIV/AIDS.

LSM peduli AIDS sebagaimana yang menjadi subjek dalam penelitian ini merupakan sebuah organisasi yang dibentuk atas dasar inisiatif anggota masyarakat Indonesia yang dilakukan secara sukarela atas kehendak sendiri dan minat yang besar serta bergerak pada bidang-bidang atau fokus tertentu yang ditetapkan oleh organisasi tersebut sebagai wujud partisipasi masyarakat dalam upaya meningkatkan taraf hidup dan kesejahteraan masyarakat yang menitikberatkan pada pengabdian secara swadaya. LSM merupakan wujud tindakan sukarela atau alturisme sehingga sering kali balas jasa (reward) yang diterima anggota organisasi LSM dalam menjalankan tugas-tugasnya tidak sebanding dengan apa yang telah dilakukannya. ${ }^{18}$

Hal tersebut juga seperti yang diungkapkan 
oleh tim penjangkauan kedua LSM baik LSM “A” maupun LSM "B" yang mengungkapkan bahwa penghasilan mereka tidak banyak dari kegiatan penjangkauan dan sosialisasi program organisasi di mana mereka terlibat. Bahkan ketika masa tenggang di mana proyek lembaga donor telah habis sambil menunggu lembaga donor baru mereka dengan ikhlas tidak dibayar selama beberapa waktu karena mereka menyadari betul keterlibatan mereka di dalam LSM adalah atas inisiatif mereka yang sebagian besar ODHA dan mantan pengguna jarum suntik untuk membantu sesama mereka sesama ODHA dan pengguna jarum suntik agar kualitas hidup mereka meningkat walaupun sebagai ODHA. Keterbatasan dana operasional LSM disatu sisi menjadi hambatan bagi bekerja dan berkembangnya LSM tapi dasar kegiatan LSM yang sukarela dan pengalaman yang sama dari masing-masing anggota khususnya tim penjangkauan di lapangan adalah mantan penasun atau sesama ODHA membuat kedua LSM peduli AIDS yang menjadi subjek penelitian ini tetap melakukan tugasnya baik dalam penjangkauan maupun sosialisasi pencegahan penyebaran HIV/ AIDS. Hal tersebut yang pada dasarnya apabila dikelola dengan baik dengan peningkatan kapasitas sumber daya manusia yang baik akan mengatasi kendala atau hambatan organisasi berbasis komunitas dalam melakukan tugas-tugas pokok dalam mencegah penyebaran virus HIV/AIDS dan penanggulangan yang lebih komprehensif.

\section{Kesimpulan}

Kendala yang dialami oleh organisasi berbasis komunitas atau LSM Peduli HIV/AIDS antara lain alur rujukan berdasarkan domisili pada sistem jaminan kesehatan BPJS, koordinasi dan kerja sama dengan fasilitas layanan kesehatan primer yaitu puskesmas yang kurang optimal, kualitas dan kapasitas SDM anggota LSM yang belum merata, persoalan-persoalan administratif organisasi, sumber dana yang tidak selalu kontinu, kebijakan darurat narkotika yang dicetuskan oleh pemerintah pusat dengan kepolisian yang berujung pada perbedaan kepentingan antar pihak-pihak berkepentingan, serta masih tingginya stigma masyarakat tentang penderita HIV/AIDS.

Good practice dari beberapa negara ASEAN dalam upaya pencegahan dan penanggulangan
HIV/AIDS dapat menjadi informasi dan pelajaran bersama, seperti pentingnya keberlanjutan dana program, pentingnya dukungan sosial dengan mengurangi stigma dan diskriminasi terhadap ODHA, serta koordinasi antara lembaga pemerintah, non pemerintah, dan masyarakat/swasta.

\section{Saran}

Beberapa rekomendasi yang dapat diberikan antara lain: memastikan semua aspek legal LSM sudah terpenuhi, mengikutsertakan anggota tim penjangkauan dalam pelatihan-pelatihan program pencegahan dan penanggulangan HIV/AIDS yang diselenggarakan secara rutin oleh lembaga pemerintah/kementerian untuk meningkatkan kapasitas dan kualitas SDM LSM, meningkatkan koordinasi LSM dengan pusat layanan kesehatan tingkat pertama (puskesmas), dan melakukan pendekatan dengan tokoh masyarakat untuk mengurangi stigma terhadap penderita HIV/AIDS. Selain itu, perlu dukungan keberlanjutan dana kegiatan.

\section{Ucapan Terimakasih}

Penulis mengucapkan terima kasih kepada Kepala Badan Litbangkes, narasumber dari kedua LSM Peduli AIDS yang menjadi tempat penelitian, para informan yang telah berpartisipasi dalam penelitian ini serta Tim Risbinkes 2015 baik Tim Pembina Ilmiah, Tim Sekretariat hingga Tim Peneliti atas bantuannya sehingga penelitian ini dapat berjalan dengan baik.

\section{Daftar Rujukan}

1. The Joint United Nations Programme on HIV/ AIDS (UNAIDS). Fact sheet: Global AIDS epidemic facts and figures 2014; 2014:1-6.

2. The Joint United Nations Programme on HIV/ AIDS (UNAIDS). The Gap Report; 2014. doi: ISBN 978-92-9253-062-4.

3. Ditjen PP\&PL Kemenkes RI. Statistik kasus HIV/AIDS di Indonesia dilapor sampai dengan September 2014. Diakses dari www.depkes. go.id $>$ download $>$ pusdatin, tanggal 7 November 2016.

4. Ditjen PP\&PL Kemenkes RI. Statistik kasus HIV/AIDS di Indonesia dilapor sampai dengan Desember 2014. Diakses dari spiritia.or.id/Stats/ 
stat2016.xls, tanggal 7 November 2016.

5. Komisi PenanggulanganAIDS Nasional. Strategi dan rencana aksi nasional penanggulangan HIV dan AIDS tahun 2010 - 2014. Jakarta: Komisi Penanggulangan AIDS Nasional; 2010.

6. Mbuagbaw L, Shurik E. Community participation in HIV/AIDS programs. In: Barros DE, ed. HIV-Infection-Impact, awarness and social implications of living with HIV/AIDS, Dr. Eugenia Barros (Ed).; 2011.

7. Pusat Kebijakan dan Manajemen Kesehatan Fakultas Kedokteran UGM. Kebijakan dan program HIV dan AIDS dalam sistem kesehatan di Indonesia. Insist Press: Yogyakarta; 2016.

8. Ramirez-Valles J. The protective effects of community involvement for HIV risk behavior: a conceptual framework. Health Educ. Res. 2002;17(4):389-403. doi:10.1093/her/17.4.389.

9. Pusat Kebijakan dan Manajemen Kesehatan Fakultas Kedokteran UGM. Tinjauan respon sektor komunitas terhadap penanggulangan HIV/AIDS, Yogyakarta, 2015.

10. Charles M. Community-Based Initiatives for HIV Program Management among Most-at-Risk Populations. Case Studies Series, Arlington, VA: USAID's AIDS Support and Technical Assistance Resource, AIDSTAR-One: Task Order 1; 2013.

11. ASEAN. Compilation of ASEAN good practices on the implementation of policies and programmes on the prevention and management of HIV \& AIDS in the workplace. The ASEAN Secretariat Jakarta; 2015.

12. Anonymous. Laporan kegiatan comparative study on financing not-for-profit organization on HIV/AIDS control programs di Australia dan Malaysia 1 - 9 Juni 2015. Diakses dari http:// www.kebijakanaidsindonesia.net/jdownloads/ Umum/option_paper_comparative_study_cso_ funding_mechanism.pdf. tanggal 1 November 2016.

13. Kementerian Kesehatan RI. SUFA, Inovasi baru dalam upaya pengendalian HIV/AIDS di Indonesia, Dipublikasikan pada : Selasa, 05 Agustus 2014 11:49:00, diakses dari http://www. depkes.go.id/article/view/201408140001/sufainovasi-baru-dalam-upaya-pengendalian-HIV/ AIDS-di-indonesia.html tanggal 1 November
2016.

14. Maharani, Elisabet A, Hesti L, and Dyah L. Evaluasi Implementasi Program Jaminan Kesehatan Masyarakat (Jamkesmas) Di Kecamatan Baturetno Kabupaten Wonogiri. Journal of Public Policy and Management Review. 2014; 3 (4): 26-34.

15. Putrawan A, Junaid, Cece S.I.. Studi Kualitatif Pelaksanaan Jaminan Kesehatan Nasional oleh BPJS Kesehatan di Kecamatan Tinanggea Kabupaten Konawe Selatan. Jurnal Ilmiah Mahasiswa Kesehatan Masyarakat. 2017; 1 (3).

16. Ogden, Jane. Health Psychology. Buckingham, Philadelphia: Open University Press; 1996.

17. Malta M, Petersen M.L, Clair S, Freitas F, \& Bastos FI. Adherence to antiretroviral therapy: a qualitative study with physicians from Rio de Janeiro, Brazil. Cadernos de saúde pública, 2005; 21: 1424-32.

18. Allison M, Jude K. Perencanaan Strategis Bagi Organisasi Nirlaba. Yayasan Pustaka Obor Indonesia; 2005.

19. Bourdieu, Pierre. The Forms of Capital, dalam J. Richardson, ed. Handbook of Theory and Research for the Sociology of Education. Westport, CT: Greenwood Press. [1983](1986).

20. Abdullah, Abdul G K, Keow N T, Aziah I. Keadilan organisasi, kepercayaan dan altruisme. Malaysian Journal of Educators and Education. 2007; 22: 75-92.

21. Shaluhiyah Z, Syamsulhuda B M, Bagoes W. Stigma masyarakat terhadap orang dengan HIV/ AIDS. Kesmas: National Public Health Journal. 2015; 9 (4): 333-9.

22. Simbayi L C, Kalichman S, Strebel A, Cloete A, Henda N, \& Mqeketo A. Internalized stigma, discrimination, and depression among men and women living with HIV/AIDS in Cape Town, South Africa. Social science \& medicine. 2007; 64 (9): 1823-31.

23. Li L, Wu Z, Wu S, Zhaoc Y, Jia M, \& Yan Z. HIV-related stigma in health care settings: a survey of service providers in China. AIDS patient care and STDs. 2007; 21(10): 753-762.

24. Maman S, Abler L, Parker L, Lane T, Chirowodza A, Ntogwisangu J, et al. A comparison of HIV stigma and discrimination in five international sites: The influence of care and treatment 
resources in high prevalence settings. Journal of Social Science \& Medicine. 2009; 68 (12): 2271-8.

25. Foster G, Williamson J. A review of current literature of the impact of HIV/AIDS on children in Sub-Saharan Africa. AIDS. 2000; 14: 275-84.

26. Butt L, Morin J, Numbery G, Peyon I, Goo A. Stigma and HIV/AIDS in highlands Papua.
Pusat Studi Kependudukan-Universitas Cenderawasih and University of Victoria. Canada: UNCEN UoV; 2010.

27. Sohn A, Park S. HIV/AIDS knowledge, stigmatizing attitudes, and related behaviors and factors that affect stigmatizing attitudes against HIV/AIDS among Korean adolescents. Osong Public Health and Research Perspectives. 2012; 3 (1): 24-30. 